\title{
Evaluation of Sulfa Drugs against Recombinant Pneumocystis carinii Dihydropteroate Synthetase and In vivo
}

\author{
YU-LONG HONG, ${ }^{1}$ PAUL HOSSLER, ${ }^{\prime}$ MARILYN BARTLETT, ${ }^{2}$ SHERRY QUEENER, ${ }^{2}$ JAMES SMITH ${ }^{2}$ AND STEVEN MESHNICK ${ }^{1}$, \\ ${ }^{\prime}$ Dept. of Epidemiology, Univ. of Michigan, Ann Arbor MI, and ${ }^{2}$ Dept. of Pathology and Lab. Medicine, Indiana University School of Medicine, Indianapolis, IN
}

Sulfa drugs are potent and important anti-pneumocystis agents, but have a high incidence of adverse effects in AIDS patients. Although 15,000 sulfa drugs have been synthesized and dozens have been used in people, relatively few have been tested against $P$. carinii. In order to determine whether there are sulfa drugs which are better antipneumocystis agents than sulfamethoxazole and dapsone, we have been testing sulfa drugs in vitro, against recombinant $P$. carinii dihydropteroate synthetase, and in vivo.

MATERIALS AND METHODS. Immunosuppression of latently infected rats, isolation of organisms, and enzyme and uptake assays were performed as previously described (1). Rats were administered drug continuously via their drinking water for the full 6 weeks of immunosuppression. Exact doses were calculated by measuring daily water consumption. After 6 weeks, the rats were sacrificed, organisms were harvested, and the total number of cysts isolated from the lungs of each rat determined. Mice were treated either prophylactically or therapeutically as previously described (2).

RESULTS AND DISCUSSION. Of the 44 sulfa drugs studied initially, 8 had IC50's between 13 and $40 \mu \mathrm{M}$ : sulfamethoxypyridazole, sulfathiazole, sulfachlorpyridazine, sulfamethoxypyridazine, sulfathiourea, sulfadimethoxine, sulfisoxazole, and sulfaquinoxaline. In general, we found that sulfonamides (Fig. 1) were more potent than sulfones. The compounds with greatest potency tended to have heterocyclic substituents on the $\mathrm{N}^{1}$ position (R1). Substituents on the p-amino group (R2) ablated activity (1).

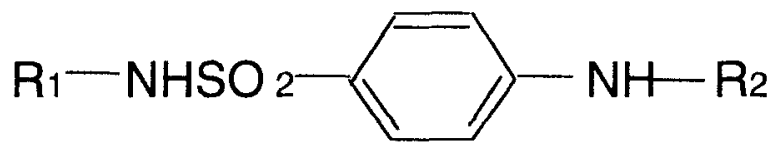

Fig. 1. Sulfonamide structure

In order for a sulfa drug to be effective, it must not only inhibit dihydropteroate synthetase but be taken up by intact organisms. To determine this, we measured the effects of selected sulfa drugs on folate metabolism in intact, isolated $P$. carinii over 2 hours. At $50 \mathrm{nM}$, sulfamethoxazole inhibited folate biosynthesis in situ by approximately half. Sulfachlorpyridazine, sulfamethoxypyridazine, sulfisoxazole, and sulfathiazole all inhibited folate biosynthesis to a similar extent at this concentration, suggesting that they are all taken up equally well by intact organisms (1).

Sulfamethoxypyridazine and sulfisoxazole were selected for testing in animals, since they have both been widely used in humans. Both drugs were tested in transtracheally-inoculated mice using both prophylactic and therapeutic regimens (Table 1). On the basis of both Giemsa and Silver scores, sulfisoxazole had moderate activity prophylactically but no activity therapeutically. In contrast, sulfamethoxypyridazine was equivalent to sulfamethoxazole both prophylactically and therapeutically.
Table 1. Effects of sulfa drugs on $P$. carinii infections in mice.

\begin{tabular}{|c|c|c|c|}
\hline \multirow[t]{2}{*}{$\overline{\text { Drug }}$} & \multirow{2}{*}{$\begin{array}{c}\text { Dose } \\
\mathrm{mg} / \mathrm{kg} / \mathrm{d}(\mathrm{No}) \text {. }\end{array}$} & \multicolumn{2}{|c|}{ Mean infection (SD) } \\
\hline & & Giemsa & Silver \\
\hline Control & $0(20)$ & $4.4(0.2)$ & $3.6(0.1)$ \\
\hline \multicolumn{4}{|l|}{ Therapy } \\
\hline Sulfisoxazole & $1.0(10)$ & $4.5(0.1)$ & $3.3(0.1)$ \\
\hline Sulfamethoxypyridazine & e $1.0(10)$ & $0.3(0.1)$ & $0.2(0.1)$ \\
\hline Sulfamethoxazole & $1.0(10)$ & $0.1(0.0)$ & $0.1(0.0)$ \\
\hline \multicolumn{4}{|l|}{ Prophylaxis } \\
\hline Sulfisoxazole & $1.0(10)$ & $1.4(0.3)$ & $1.6(0.2)$ \\
\hline Sulfamethoxypyridazine & $1.0(10)$ & $0.1(0.1)$ & $0.1(0.1)$ \\
\hline Sulfamethoxazole & $1.0(10)$ & $0.1(0.0)$ & $0.0(0.0)$ \\
\hline
\end{tabular}

Both drugs were also tested as prophylactic agents in latently infected rats (Table 2). Sulfisoxazole had no significant activity (not shown), whereas sulfamethoxypyridazine caused a $>99 \%$ reduction in cyst counts at all doses tested.

Table 2. Effects of sulfamethoxypyridazine on $P$. carinii infections in rats

\begin{tabular}{llll}
\hline \hline $\begin{array}{l}\text { Dose } \\
(\mathrm{mg} / \mathrm{kg} / \mathrm{d})\end{array}$ & $\begin{array}{l}\text { No. } \\
\text { rats }\end{array}$ & $\begin{array}{l}\text { Percent } \\
\text { reduction }\end{array}$ & $\begin{array}{l}\mathrm{P} \\
\text { value }\end{array}$ \\
\hline 15.4 & 4 & 99.8 & 0.02 \\
0.4 & 5 & 99.5 & 0.05 \\
0.13 & 4 & 99.3 & 0.03 \\
\hline
\end{tabular}

In summary, sulfamethoxypyridazine was effective both prophylactically and therapeutically in mice and at impressively low doses in rats. The lowest dose tested in rats was $1 / 40$ th the sulfa dose received by patients on Bactrim prophylaxis (approximately $6 \mathrm{mg} / \mathrm{kg} / \mathrm{d}$ ) and $1 / 20$ th the the minimum effective dose of sulfamethoxazole in rats (3). It is possible that lower doses of sulfamethoxypyridazine, which are now being tested, may also prove to be effective. Sulfamethoxypyridazine deserves further consideration as an antipneumocystis drug for other reasons as well. First, it may possibly be associated with fewer adverse effects than sulfamethoxazole (4). Second, it has a longer half-life than sulfamethoxazole (5) making it more appropriate for prophylaxis. [Supported by NIH grants RO1-AI 31775, UO1-AI35203 and NO1-AI-35171.]

1. Hong YL, Hossler PA, Calhoun DH, Meshnick SR. Antimcrob. Agents Chemother, (1995) 39:1756-1763.

2. Bartlett MS, Queener SF, Durkin MM, Shaw MA, Smith JW. Diagn. Microbiol. Infect. Dis. (1992) 15:129-134.

3. Walzer PD, Foy J, Steele P, Kim CK, White M, Klein RS, Otter BA, Allegra C. Antimcrob. Agents Chemother. (1992) 36:1935-1942.

4.Bjorkman A, Phillips-Howard PA. Bull. W.H.O. (1991) 69:297-304.

5. Anand N. In: Wolff M. Burger's Medicinal Chemistry (1980) Wiley Interscience, NY. 1-20. 